\title{
Study of an abnormal occurrence of Oxisols in strongly undulated relief in the south of Minas Gerais, Brazil, with support of $\mathrm{pXRF}$ and geomorphology
}

\section{Estudo da ocorrência rara de Latossolos em relevo forte ondulado no sul de Minas Gerais, Brasil, com apoio de pXRF e geomorfologia}

\author{
Fernanda Almeida Bócoli ${ }^{1} \oplus$, Walbert Júnior Reis dos Santos ${ }^{2} \odot$, Sérgio Henrique Godinho Silva ${ }^{1} \odot$, \\ Anita Fernanda dos Santos Teixeira ${ }^{1} \odot$, Marcelo Mancini ${ }^{1} \odot$, Nilton Curi ${ }^{1 *} \odot$
}

\author{
'Universidade Federal de Lavras/UFLA, Departamento de Ciência do Solo/DCS, Lavras, MG, Brasil \\ 2Instituto Federal de Educação, Ciência e Tecnologia do Sul de Minas Gerais/IFSULDEMINAS, Muzambinho, MG, Brasil \\ ${ }^{*}$ Corresponding author: niltcuri@ufla.br \\ Received in August 20, 2021 and approved in October 15, 2021
}

\begin{abstract}
Oxisols are the main soils in Brazil and they classically occur in stable and gentle geomorphic surfaces. However, in the south of Minas Gerais State, Oxisols have been observed under strongly undulated relief, a very rare condition for these soils in this physiographic region. Therefore, this work aimed to assess the elemental dynamics and relief enhanced with portable X-ray fluorescence (pXRF) spectrometry, associated to geomorphology, to understand such occurrence. The studied soils are located in Muzambinho municipality, Minas Gerais State, Brazil. Oxisol profiles were characterized in the upper third (P1), middle third (P2) and lower third (P3) of the hillslope. After morphological description, soil samples were collected in the $A, A B$ and Bo horizons of the profiles. Physical, chemical and pXRF analyses of the soils were carried out in the laboratory. Ti and Fe content (PXRF) had a high correlation with the soil textural fractions. High weathering-leaching degrees were determined, although they occur on a steep slope where younger soils (Inceptisols) would be expected in this region. The altitudinal concordance of summits observed in the more elevated surrounding areas indicates a flat paleorelief, helping to explain this unusual occurrence. The soils' weathering degree values decreased down the hillslope, indicating silica enrichment through runoff and subsuperficial water flux in the lower landscape positions. The PXRF analyses assisted the characterization of these old soils occurring in steep relief. It provided bases for confirming their high weathering degree indexes and detected evidences of the pre-weathering of the regolith of this very old landscape.
\end{abstract}

Index terms: Steep slopes; proximal sensors; tropical soils; weathering.

\section{RESUMO}

Latossolos são os principais solos do Brasil e classicamente ocorrem em superfícies geomórficas suavizadas e estáveis. No entanto, no Sul de Minas Gerais, Latossolos têm sido observados em relevo forte ondulado, uma condição rara para estes solos nesta região fisiográfica. Este trabalho teve como objetivo acessar a dinâmica elementar e o relevo com uso de espectrometria de fluorescência de raios-X portátil (pXRF), em associação à geomorfologia, para entender tal ocorrência. Os solos estudados estão localizados no município de Muzambinho, Estado de Minas Gerais, Brasil. Perfis de Latossolo foram caracterizados no terço superior (P1), terço médio (P2) e terço inferior (P3) da encosta. Após a descrição morfológica, amostras de solo foram coletadas nos horizontes $A$, AB e Bw dos perfis. Foram realizadas análises físicas, químicas e espectrométricas dos solos em laboratório. Os teores de Ti e Fe (pXRF) tiveram alta correlação com as frações texturais dos solos. Foram encontrados altos graus de intemperismo-lixiviação dos Latossolos, embora ocorram em encosta íngreme onde solos mais jovens (Cambissolos) seriam esperados. A concordância de altitude dos topos observada nas áreas circundantes mais elevadas indica um paleorrelevo plano, ajudando a explicar esta ocorrência anormal. Os valores dos índices de intemperismo dos solos diminuíram ao longo da encosta, indicando o enriquecimento de sílica por escoamento superficial e fluxo de água subsuperficial nas posições mais baixas da paisagem. As análises de pXRF ajudaram na caracterização destes solos velhos em topografia forte ondulada. O equipamento forneceu bases para confirmação dos seus altos graus de intemperismo, além de detectar evidências do pré-intemperismo do regolito dessa paisagem muito antiga.

Termos para indexação: Encostas íngremes; sensores próximos; solos tropicais, intemperismo. 


\section{INTRODUCTION}

Latosols (Santos et al., 2018), Oxisols (Soil Survey Staff, 2014) or Ferralsols (Food and Agriculture Organization - FAO, 2014) are the most important and widely distributed soils in Brazil. In general, Brazilian Oxisols are highly weathered-leached, which causes the residual accumulation of $\mathrm{Fe}, \mathrm{Al}$ and $\mathrm{Ti}$ oxide minerals, and removal of silica and bases, acidifying these soils (Ker, 1998). They commonly have as advantages the microgranular structure in the Bo horizon, good drainage, high effective depth, and adequate balance of macro- and micropores for root system growth and crop development.

A relevant factor for Oxisols formation is the relief (Jenny, 1941), generally occurring under slopes ranging from flat to gently undulated (Resende et al., 2014, 2021). The relief conditions soil formation by affecting the water flow and the transportation of soil constituents (Campos et al., 2012; Canellas et al., 2000). Accordingly, it is a paramount factor driving soil differentiation across the landscape (Kämpf; Curi, 2012).

However, some Oxisols are found in steep slopes, an atypical condition for their occurrence. Presumably, since Oxisols are intensely weathered and deep, they should need a smoother surface to fully develop, where pedogenetic processes are more intense than erosion, otherwise they would remain as young soils and never develop enough to be classified as Oxisols. Thus, the reasons behind their occurrence in strongly undulated relief are not completely understood by soil scientists.

The development of these soils under a paleorelief can explain this occurrence. These soils may have formed when landforms were very different from the modern age, when the region was flatter, followed by a later dissection of the landscape, but still maintaining their classification as Oxisols (Resende et al., 2014; Rezende et al., 2021), unless the thickness of Bo horizon is less than $50 \mathrm{~cm}$, framing them alternatively as Inceptisols, which is not the situation in this study. The investigation of such cases can enrich the literature and complement the current knowledge about soil formation. Novel technologies might be able to aid this endeavor, such as the portable X-ray fluorescence (pXRF).

The pXRF provides the total elemental content of samples and has been successfully employed in many soil studies (Silva et al., 2021; Weindorf; Bakr; Zhu, 2014). It has been adopted for the study of several soil properties, such as texture (Zhu; Weindorf; Zhang, 2011), soil nutritional analysis (Lima et al., 2019; Pelegrino et al., 2021), soil biology (Teixeira et al., 2021), soil mapping (Mancini et al., 2019; Silva et al., 2016), soil genesis and classification (Gozukara; Zhang; Hartemink, 2021; Silva et al., 2018, 2021; Stockmann et al., 2016; Sun et al., 2020), characterization of different land uses (Chakraborty et al., 2019), soil salinity (Swanhart et al., 2014), soil contamination (Horta et al., 2021; Kebonye, 2021), among others, showing up as a useful tool for such studies.

Seemingly, it could be applied for soil weathering studies. As soils develop, some oxides residually accumulate, such as $\mathrm{Al}_{2} \mathrm{O}_{3}, \mathrm{Fe}_{2} \mathrm{O}_{3}, \mathrm{TiO}_{2}$. Weathering indexes relate these oxides with silica $\left(\mathrm{SiO}_{2}\right)$, which is leached during soil formation, attempting to measure the degree of weathering (Santos et al., 2018). The usual approach is to calculate the silica/alumina or the silica/ (alumina $+\mathrm{Fe}_{2} \mathrm{O}_{3}$ ) ratios (Zhang, Hartemink, 2019); but alternatively, one can relate all mentioned oxides, as proposed by Singh, Parkash and Singhvi (1998). The oxides needed for these indexes are commonly obtained by laboratory analysis, but sensors like pXRF are able to provide such data and simplify the methodology.

Thus, this work aimed to assess the aspects of elemental dynamics, weathering and geomorphology of old soils observed under unusual steep relief enhanced by pXRF spectrometry to understand such abnormality. The hypothesis is that the chemical characterization provided by pXRF and its association with geomorphology will improve our knowledge about tropical soils formation. Although in tropical conditions the use of pXRF has increased, without generation of chemical waste ("green analyses") (Silva et al., 2021), this approach was not yet applied to investigate and characterize Oxisols that occur in steep relief. The lowcost and agile methods enabled by pXRF could allow for quick and effective analyses, providing important insights regarding the formation of such soils.

\section{MATERIAL AND METHODS}

\section{Study area, soil profiles description and sampling}

The study area is located at the Atlantic Forest biome, in the Instituto Federal de Educação, Ciência e Tecnologia do Sul de Minas Gerais (IFSULDEMINAS), in the Muzambinho municipality, south of Minas Gerais State, Brazil. In the IFSULDEMINAS campus, Oxisols represent $53 \%$ of the total area; from them, $11 \%$ are located in slopes steeper than 20\% (Batista; Santos, 2017). The parent material of these Oxisols is gneiss (Table 1). According to Köppen's classification, the climate in this region is $\mathrm{Cwb}$ (temperate humid climate, with dry winters and rainy summers). The mean annual temperature is $18{ }^{\circ} \mathrm{C}$ and the mean annual rainfall 
is 1,605 mm (Alvares et al., 2013; Aparecido et al., 2014). The main native vegetation is represented by the semiperennial tropical forest.

Table 1: Example of the chemical composition of gneiss fragments obtained via pXRF in Lavras, Minas Gerais, Brazil. Adapted from Mancini et al. (2019).

\begin{tabular}{cr}
\hline \multicolumn{2}{c}{ Gneiss chemical composition } \\
\hline \multicolumn{2}{l}{ Total elemental content (\%) } \\
\hline $\mathrm{Al}$ & 15.037 \\
$\mathrm{Ca}$ & 0.665 \\
$\mathrm{Fe}$ & 0.713 \\
$\mathrm{~K}$ & 0.563 \\
$\mathrm{Mg}$ & 1.301 \\
$\mathrm{Mn}$ & 0.001 \\
$\mathrm{P}$ & 0.038 \\
$\mathrm{Si}$ & 35.317 \\
$\mathrm{Ti}$ & 0.127 \\
\hline
\end{tabular}

Soil profiles were morphologically described and sampled on a strongly undulated relief under a planted pasture area (Figure 1). Profile 1 (P1) is located in the upper third of the hillslope, coordinates $21^{\circ} 21^{\prime} 06^{\prime \prime} \mathrm{S}$ and $46^{\circ} 31^{\prime} 41^{\prime \prime} \mathrm{W}$; profile $2(\mathrm{P} 2)$, in the middle third of the hillslope, coordinates $21^{\circ} 21^{\prime} 07^{\prime \prime} \mathrm{S}$ and $46^{\circ} 31^{\prime} 40^{\prime \prime}$ $\mathrm{W}$; and profile $3(\mathrm{P} 3)$, in the lower third of the hillslope, coordinates $21^{\circ} 21^{\prime} 09^{\prime \prime} \mathrm{S}$ and $46^{\circ} 31^{\prime} 39^{\prime \prime} \mathrm{W}$. The slope on these soil profiles is shown in Figure 1. The altitude ranged from $945 \mathrm{~m}$ in $\mathrm{P} 3$ to $1,025 \mathrm{~m}$ in $\mathrm{P} 1$ (Figure 1). The horizontal distance from $\mathrm{P} 1$ to $\mathrm{P} 2$ is $42 \mathrm{~m}$, and from $\mathrm{P} 2$ to $\mathrm{P} 3,75 \mathrm{~m}$. The slope on each point is: $\mathrm{P} 1-18.3 \%$, $\mathrm{P} 2-25.7 \%$, P3 $-29.2 \%$. The soils were classified as Latossolo Vermelho-Amarelo distrófico típico (P1 and P2) and Latossolo Amarelo distrófico típico (P3) (Santos et al., 2018), corresponding to Typic Hapludox (P1 and P2) and Xanthic Hapludox (P3), according to US Soil Taxonomy (Soil Survey Staff, 2014), and to Haplic Ferralsol (P1 and P2) and Xanthic Ferralsol (P3), according to the Word Reference Base (FAO, 2014). The different classification systems were presented for reference, but studied soils will be addressed using the US Soil Taxonomy throughout the text for consistency.

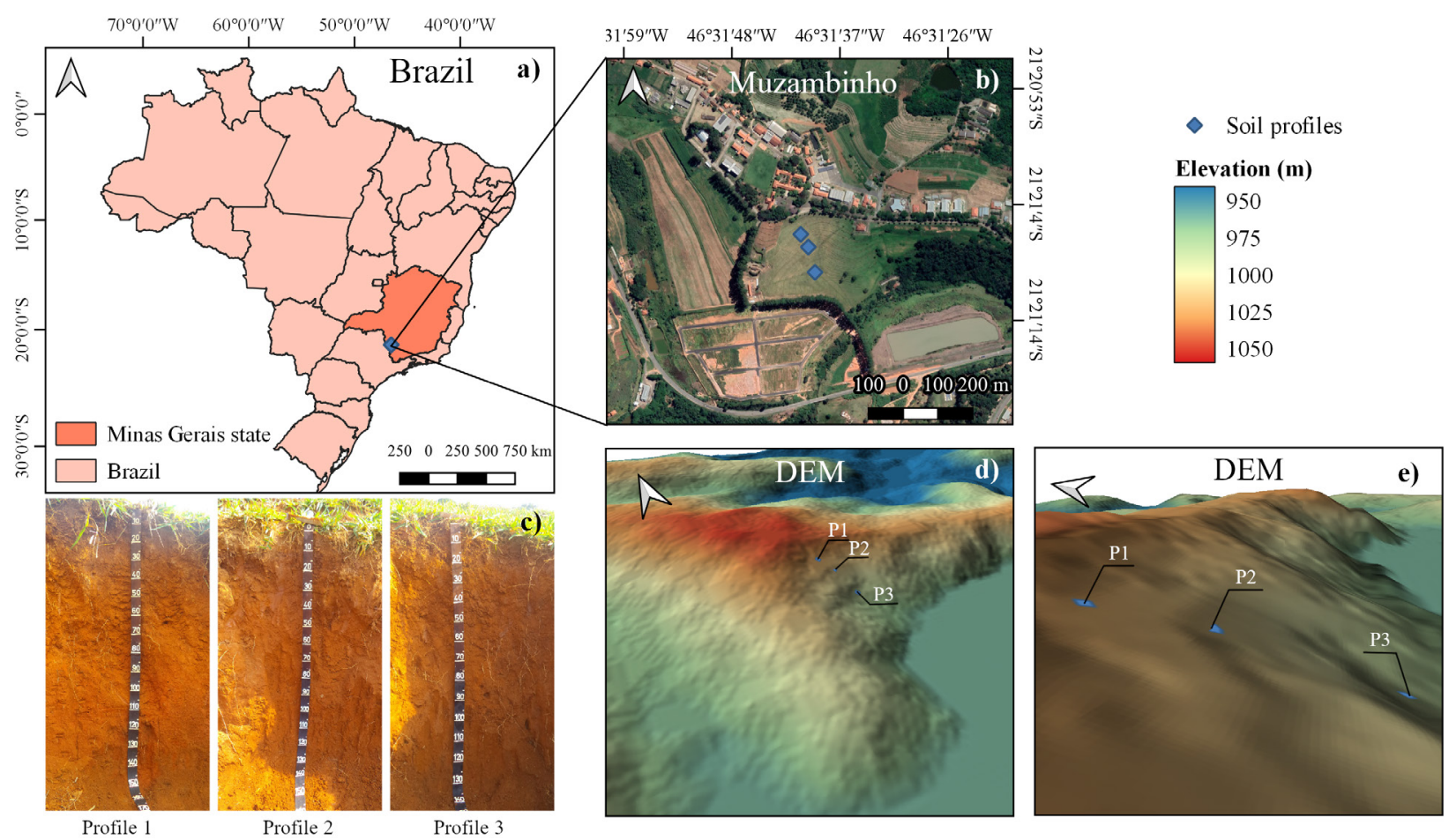

Figure 1: Location of the study area ( $a$ and b), studied soil profiles (c) and the respective digital elevation model ( $d$ and e). The area is located in the Muzambinho municipality, south of Minas Gerais State, Brazil. P1: Profile 1; P2: Profile 2; P3: Profile 3, DEM: Digital elevation model. 
Profile morphological description was conducted as suggested by Santos et al. (2015). Composite samples of the $\mathrm{A}, \mathrm{AB}$, and Bo horizons were collected to perform the chemical, physical and $\mathrm{pXRF}$ analyses.

\section{Soil texture and fertility analyses}

The collected samples were air-dried and sieved ( $2 \mathrm{~mm}$ ) (air-dried fine earth -ADFE) for the chemical and texture analyses. The $\mathrm{pH}$ was obtained in water (soil:water ratio of 1:2.5) (Donagema et al., 2011). Exchangeable contents of $\mathrm{Ca}^{2+}, \mathrm{Mg}^{2+}$, and $\mathrm{Al}^{3+}$ were obtained by extraction with $1 \mathrm{~mol} \mathrm{~L}^{-1} \mathrm{KCl}$ (Mclean et al., 1958). Available contents of $\mathrm{K}^{+}$and $\mathrm{P}$ were obtained by extraction utilizing Mehlich-1 solution (Mehlich, 1953); $\mathrm{H}^{+}+\mathrm{Al}^{3+}$ were determined by the SMP extractor (Shoemaker; Mclean; Pratt, 1961). The available B was determined using hot water as proposed by Berger and Truog (1939) and the available $\mathrm{Cu}, \mathrm{Zn}, \mathrm{Mn}$, and Fe were extracted with Mehlich-1 solution and measured through the atomic absorption spectrometry (Mehlich, 1953).

Soil organic matter (SOM) content was determined according to Walkley and Black (1934). Cation exchange capacity (CEC) was calculated by the sum of $\mathrm{Ca}^{2+}, \mathrm{Mg}^{2+}$, $\mathrm{K}^{+}, \mathrm{Al}^{3+}$ and $\mathrm{H}^{+}$contents. Particle size distribution analysis was performed by the pipette method according to Gee and Bauder (1986).

\section{Analyses via pXRF spectrometry}

The pXRF analyses of ADFE samples were conducted on a DP-600 (Olympus Waltham, MA) spectrometer, during 60 seconds, operating in Soil Mode (Silva et al., 2021; Weindorf; Chakraborty, 2016). To ensure the efficiency of this proximal sensor, two soil materials certified by the National Institute of Standards and Technology (NIST), 2710a, and 2711a, and a material provided by the pXRF manufacturer (check sample) were analyzed by $\mathrm{pXRF}$ and the obtained contents were compared with the certified values.

Five elements were used in this study due to their importance as soil weathering indicators (Ker; Novais, 2011; Resende et al., 2019): Ti, Mn, Si, Al and Fe. All the recovery values of these elements (content yielded by $\mathrm{pXRF} /$ certified content $\mathrm{x} 100$ ) were higher than $70 \%$. From these results, indexes traditionally used in the literature, as cited below (Equations 1, 2 and 3), were applied to assess soil weathering. The following soil weathering indexes were calculated using oxide total values obtained by pXRF:
$\mathrm{Di}=\frac{\mathrm{SiO}_{2}}{\left(\mathrm{Al}_{2} \mathrm{O}_{3}+\mathrm{Fe}_{2} \mathrm{O}_{3}+\mathrm{TiO}_{2}\right)}$

(Singh; Parkash; Singhvi, 1998)

$$
\mathrm{Ri}=\frac{\mathrm{SiO}_{2}}{\mathrm{Al}_{2} \mathrm{O}_{3}}
$$

(Ruxton, 1968)

$\mathrm{Zi}=\frac{\mathrm{SiO}_{2}}{\left(\mathrm{Al}_{2} \mathrm{O}_{3}+\mathrm{Fe}_{2} \mathrm{O}_{3}\right)}$

(Zhang, Hartemink, 2019)

\section{Statistical analyses and geographic information}

Pearson's correlation between the elements obtained by pXRF analyses and both texture and soil fertility results were calculated with the aid of the $\mathrm{R}$ software (R Core Team, 2021), using the package corrplot (Wei; Simko, 2021) that also calculated the significance of the results. A digital elevation map for the region was applied to analyze the morphology of the landscapes and it was obtained from the Alaska Satellite Facility Distributed Active Archive Data Center (ASF DAAC), with a resolution of $12.5 \mathrm{~m}$. The elevation data was used to visualize cross sections cutting through the studied area's relief, in order to examine the hilltop altitudes surrounding the region. This analysis was performed via the software QGIS (version 3.12.3).

\section{RESULTS AND DISCUSSION}

\section{Morphological, physical and fertility properties of the soil profiles}

The soil structure found in the three profiles was granular in the A horizon, and microgranular in the Bo horizon. In all the analyzed profiles, roots were observed in depth, which indicates adequate porosity for soil aeration and good drainage, attributes compatible with clayey Oxisols with such structure. Table 2 shows the main morphological attributes identified in the three soil profiles.

Profiles 1 and 2 presented dominant red-yellow color, while profile 3 presented yellow color in the Bo horizon (Table 2). There are several aspects to be considered in pedogenic studies that influence soil color, such as soil mineralogy, drainage class, soil water regime, soil organic matter (SOM), past and current climate, among others (Ibáñez-Asensio et al., 2013; Ker et al., 2012; Lepsch, 2010; Resende et al., 2011). In this context, the 
iron oxide minerals have remarkable importance. The clay fraction of soil profiles 1 and 2 have both hematite and goethite, while profile 3 presents only goethite (data not shown), which is in accordance with their colors.

In the $\mathrm{P} 1$ and $\mathrm{P} 2$ profiles, the hue in the superficial horizons is brown, but not below. In the P3 profile, all the horizons are brown, reflecting a subtle hydrosequence of soils conditioned by the relief (Curi; Franzmeier, 1984). Down the slope, soils get closer to the parent material, hence drainage is reduced and the tendency of accumulation of SOM increases, darkening the horizon notice the chroma/value of 4/4 in P3 below $27 \mathrm{~cm}$, lower than other profiles in the same depth.

Slight texture variations were observed among the soil profiles (Figure 2). The texture of the soil profiles varied between clayey and very clayey, indicating the high degree of weathering of these soils (Resende et al., 2019), derived from gneiss.

Table 2: Soil classes, horizons, depth, Munsell color, and structure of the three profiles located at the IFSULDEMINAS, Muzambinho municipality, Minas Gerais state, southeastern Brazil.

\begin{tabular}{|c|c|c|c|c|c|c|c|}
\hline Profile & $\begin{array}{c}\text { Soil } \\
\left(U^{1}\right)\end{array}$ & $\begin{array}{c}\text { Soil } \\
\left(\text { WRB }^{2}\right)\end{array}$ & $\begin{array}{c}\text { Soil } \\
\left(\mathrm{SiBCS}^{3}\right)\end{array}$ & Horizon & $\begin{array}{c}\text { Depth } \\
\text { (cm) }\end{array}$ & Moist color & Structure \\
\hline \multirow{3}{*}{1} & \multirow{3}{*}{$\begin{array}{c}\text { Typic } \\
\text { Hapludox }\end{array}$} & \multirow{3}{*}{$\begin{array}{l}\text { Haplic } \\
\text { Ferralsol }\end{array}$} & \multirow{3}{*}{$\begin{array}{c}\text { Latossolo } \\
\text { Vermelho- } \\
\text { Amarelo } \\
\text { distrófico típico }\end{array}$} & A & $0-20$ & Dark reddish brown (5YR 3/3) & Granular \\
\hline & & & & $A B$ & $20-27$ & Reddish brown (5YR 5/4) & Granular \\
\hline & & & & Bo & $27-300+$ & Yellowish red (5YR 5/6) & Microgranular \\
\hline \multirow{3}{*}{2} & \multirow{3}{*}{$\begin{array}{c}\text { Typic } \\
\text { Hapludox }\end{array}$} & \multirow{3}{*}{$\begin{array}{l}\text { Haplic } \\
\text { Ferralsol }\end{array}$} & \multirow{3}{*}{$\begin{array}{c}\text { Latossolo } \\
\text { Vermelho- } \\
\text { Amarelo } \\
\text { distrófico típico }\end{array}$} & A & $0-13$ & Reddish brown (5YR 4/3) & Granular \\
\hline & & & & $A B$ & $13-27$ & Reddish brown (5YR 4/4) & Granular \\
\hline & & & & Bo & $27-300+$ & Yellowish red (5YR 5/7) & Microgranular \\
\hline \multirow{3}{*}{3} & \multirow{3}{*}{$\begin{array}{l}\text { Xanthic } \\
\text { Hapludox }\end{array}$} & \multirow{3}{*}{$\begin{array}{l}\text { Xanthic } \\
\text { Ferralsol }\end{array}$} & \multirow{3}{*}{$\begin{array}{c}\text { Latossolo } \\
\text { Amarelo } \\
\text { distrófico típico }\end{array}$} & A & $0-20$ & Dark brown (7.5YR 3/3) & Granular \\
\hline & & & & $A B$ & $20-27$ & Strong brown (7.5YR 5/6) & Granular \\
\hline & & & & Bo & $27-300+$ & Brown (7.5YR 4/4) & Microgranular \\
\hline
\end{tabular}

${ }^{1}$ US Soil Taxonomy (Soil Survey Staff, 2014); ${ }^{2}$ World Reference Base (FAO, 2014); ${ }^{3}$ Brazilian Soil Classification System (Santos et al., 2018).

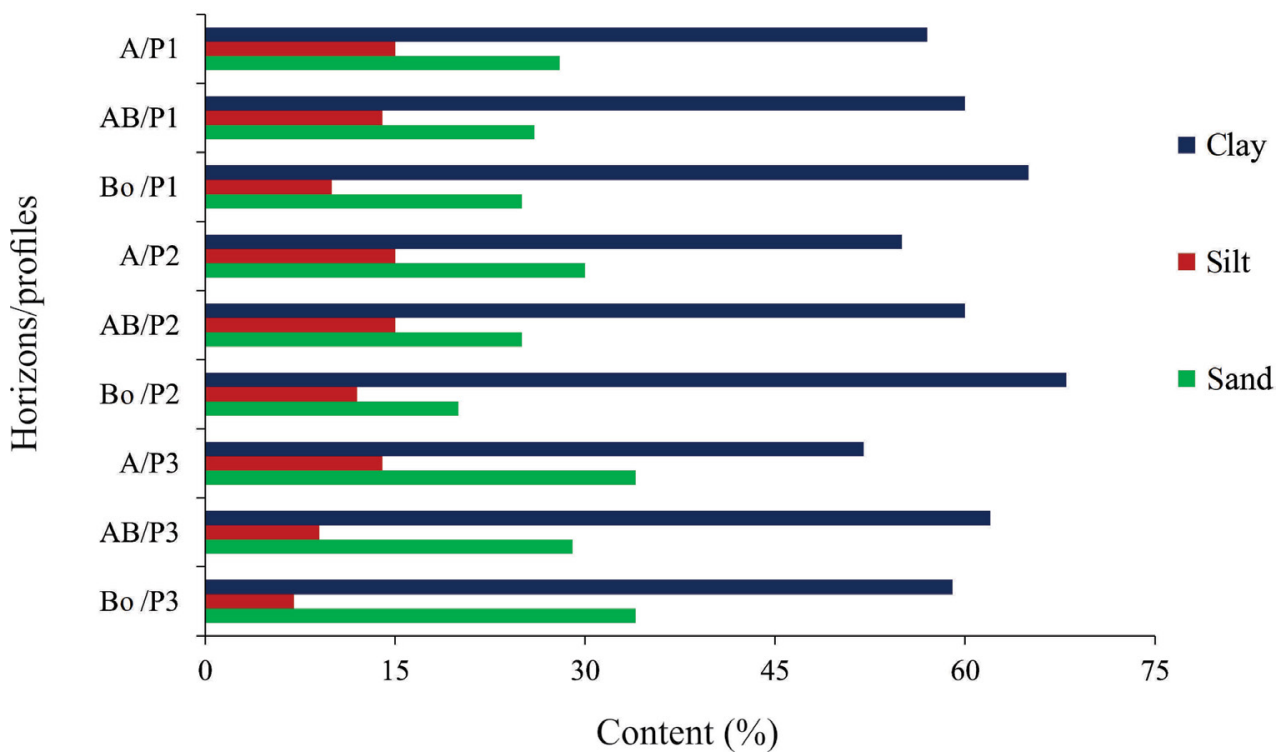

Figure 2: Particle size distribution of the soil profiles horizons located at the IFSULDEMINAS, Muzambinho municipality, Minas Gerais State, southeastern Brazil. 
Soil fertility analyses (Table 3) showed that the superficial horizons of three profiles had $\mathrm{pH}$ values higher than commonly found in Oxisols under natural conditions, which tend to be more acidic (Lopes; Guilherme, 2016). These high $\mathrm{pH}$ values along with the $\mathrm{Ca}^{2+}$ contents in the superficial horizons indicate that these planted pasture areas have received limestone.

Both SOM and CEC decrease with depth. The mutual decrease of both variables shows how these weathered soils depend on SOM to retain cations, reinforcing the importance of SOM on the generation of negative superficial charges for retaining bases in these low-activity clay soils. SOM increases down the slope in Bo, being highest in P3. This indicates a slight poorer drainage in P3 helping to preserve SOM. These soils contain kaolinite, gibbsite, hematite (except in profile 3 ) and goethite in the clay fraction which have very low CEC. Fe and Al mineral oxides, such as hematite, goethite and gibbsite at $\mathrm{pH}$ values below 7.0 tend to present anion exchange capacity (AEC) greater than CEC (Fageria, 2012). Conversely, in soils with such $\mathrm{pH}$ values SOM and kaolinite generate negative superficial charges, thus contributing to the increase of CEC (Franks et al., 2021; Inda Junior et al., 2017).

The base saturation (BS) values, except for the superficial horizons, are low, as expected for Oxisols. In the A horizon, the liming application helps to explain the higher values. The low aluminum saturation (AS) values are related to $\mathrm{Al}$ constant consumption for gibbsite formation (Curi; Franzmeier, 1984) in addition to liming application in the superficial horizons.

\section{Soil total element contents obtained by pXRF}

Figure 3 presents the pXRF results for $\mathrm{Al}, \mathrm{Si}, \mathrm{Fe}$, $\mathrm{Ti}$ and $\mathrm{Mn}$. In P1 and P2, there was a high content of $\mathrm{Al}$ in comparison to $\mathrm{Si}$ (Figure $3 \mathrm{a}$ ), evidencing the high weathering degree in these soil profiles. During the weathering process, easily-weatherable primary minerals (EWPM) suffer hydrolysis and hence can form kaolinite and iron and aluminum oxides (Inda Junior et al., 2017; Kämpf; Curi, 2003; Kämpf; Curi; Marques, 2009). Campos et al. (2012) studied the soil-landscape relationships and verified that the formation, persistence and elemental contents of clay minerals were mainly conditioned by relief. However, the mineralogy of soils herein does not match their landscape position: more primary minerals are expected in soils formed under steep slopes, instead of oxide-rich old soils with low Si content.

Compared to P1 and P2, P3 showed an increment in the Si content (Figure 3a), evidencing a relative decrease in the soil weathering degree, associated with a longer water residence time, conditioned by relief (lower third of the landscape) through silica addition from runoff and subsuperficial water flux (Moniz; Buol, 1982). In this study, where soils are derived from gneiss, differential Si contents among the profiles may indicate their differential weathering degrees driven mainly by relief conditions (Figures $3 a$ and $3 b$ ).

Different patterns of $\mathrm{Al}$ and $\mathrm{Fe}$ across horizons for each profile probably reflect the variation of parent material chemical traits (Figure 3a). P3 had a higher Si content compared with $\mathrm{Al}$ and $\mathrm{Fe}$. Silva et al. (2020) found lower contents of $\mathrm{Fe}_{2} \mathrm{O}_{3}$ and $\mathrm{TiO}_{2}$ and greater contents of $\mathrm{SiO}_{2}$ in soils derived from gneiss compared to soils developed from itabirite, basalt, gabbro and tuffite.

Table 3: Fertility analyses of Oxisol profiles located at the IFSULDEMINAS, Muzambinho municipality, Minas Gerais state, southeastern Brazil.

\begin{tabular}{|c|c|c|c|c|c|c|c|c|c|c|c|c|c|c|c|c|c|}
\hline \multirow{2}{*}{ Soil } & \multirow{2}{*}{ Hor. } & $\mathrm{pH}$ & $\mathrm{H}+\mathrm{Al}$ & $\mathrm{Al}^{3+}$ & CEC & SOM & $\mathrm{P}$ & $\mathrm{K}^{+}$ & $\mathrm{Ca}^{2+}$ & $\mathrm{Mg}^{2+}$ & BS & AS & $\mathrm{Fe}$ & $\mathrm{Mn}$ & $\mathrm{Zn}$ & $\mathrm{Cu}$ & B \\
\hline & & & \multicolumn{4}{|c|}{-----cmol $\mathrm{dm}^{-3}$----- dag kg-1 } & \multicolumn{2}{|c|}{$\mathrm{mg} \mathrm{dm}^{-3}$} & \multicolumn{2}{|c|}{$\mathrm{cmol}_{\mathrm{c}} \mathrm{dm}^{-3}$} & \multicolumn{2}{|c|}{-----\%---- } & \multicolumn{5}{|c|}{ 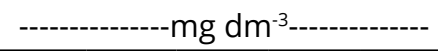 } \\
\hline & A & 6.54 & 3.38 & 0.15 & 5.5 & 2.48 & 0.6 & 26 & 1.95 & 0.11 & 38.67 & 6.59 & 82.4 & 8.9 & 0.9 & 2.3 & 0.16 \\
\hline \multirow[t]{3}{*}{ P1 } & $A B$ & 5.63 & 3.38 & 0.28 & 4 & 1.64 & 0.6 & 15 & 0.5 & 0.04 & 14.46 & 32.62 & 42.8 & 3.4 & 0.2 & 2.3 & 0.18 \\
\hline & Bo & 5.59 & 2.29 & 0.06 & 2.4 & 0.54 & 0.2 & 0 & 0.1 & 0.02 & 5.00 & 33.33 & 18.6 & 1.4 & 0.2 & 1.7 & 0.11 \\
\hline & A & 6.98 & 1.65 & 0 & 7.9 & 3 & 1.2 & 29 & 4.46 & 1.77 & 79.80 & 0 & 57.3 & 19.6 & 1. & 1.8 & 0.18 \\
\hline \multirow[t]{3}{*}{ P2 } & $A B$ & 6.81 & 1.84 & 0 & 4.6 & 1.52 & 0.6 & 9 & 2.36 & 0.4 & 60.50 & 0 & 27.3 & 4 & 0.2 & 2.1 & 0.2 \\
\hline & Bo & 5.74 & 2 & 0 & 2.4 & 0.86 & 0.2 & 4 & 0.37 & 0.02 & 16.68 & 0 & 21 & 1.5 & 0.2 & 1.5 & 0.15 \\
\hline & A & 6.69 & 3.08 & 0 & 4.8 & 2.36 & 0.9 & 32 & 1.32 & 0.31 & 35.67 & 9.51 & 74.6 & 14.6 & 0.6 & 2.1 & 0.2 \\
\hline \multirow[t]{2}{*}{ P3 } & $A B$ & 5.6 & 3.08 & 0.41 & 3.3 & 1.18 & 0.2 & 8 & 0.22 & 0.02 & 7.89 & 61.15 & 32 & 3.8 & 0.2 & 1.7 & 0.16 \\
\hline & Bo & 5.52 & 3.56 & 0.37 & 3.7 & 0.97 & 2.1 & 0 & 0.13 & 0.02 & 4.05 & 71.15 & 34.5 & 5.3 & 0.2 & 1.4 & 0.15 \\
\hline
\end{tabular}

CEC: Cation exchange capacity; SOM: Soil organic matter; BS: Base saturation; AS: Aluminum saturation. 


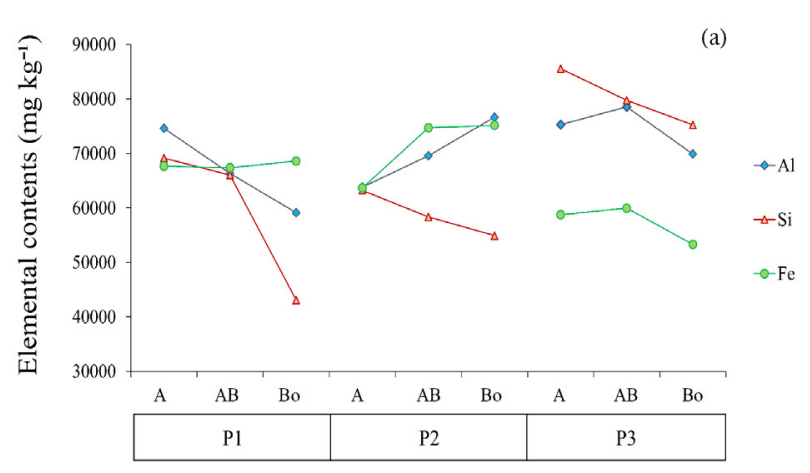

Analyzed profiles and their horizons

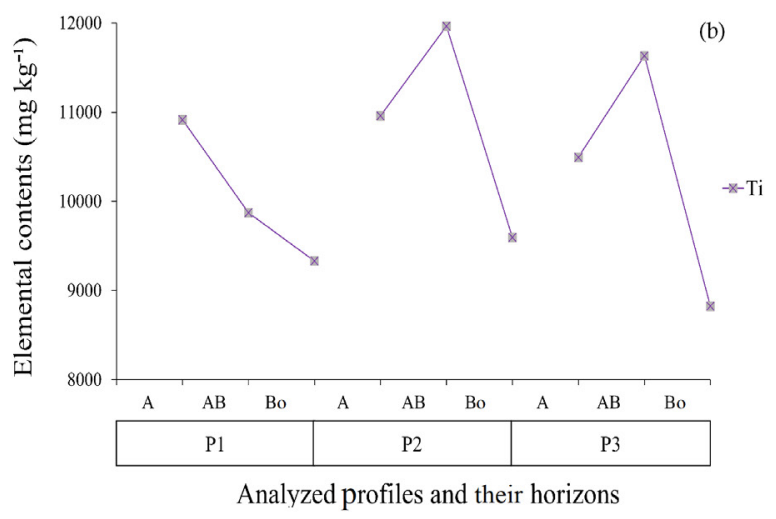

(c)

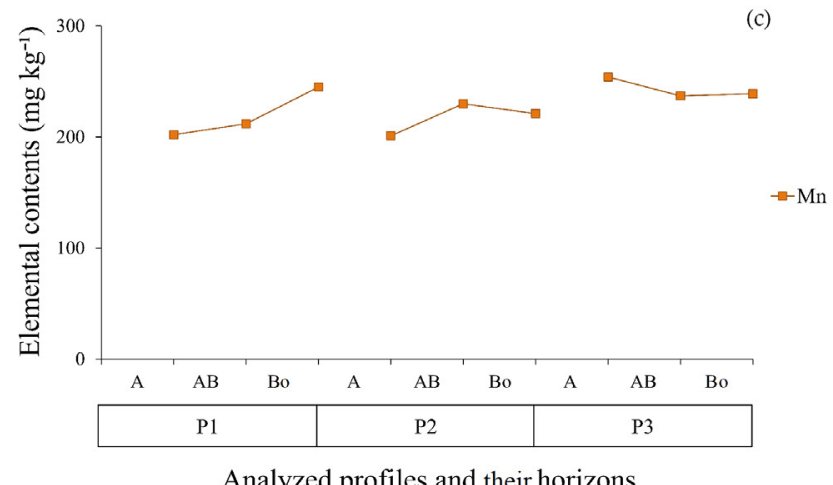

Figure 3: Elemental contents obtained by pXRF in the studied horizons of Oxisol profiles located at the IFSULDEMINAS, Muzambinho municipality, Minas Gerais state, southeastern Brazil.

The Fe content varied less in the soils in upper and middle third of the landscape $(\mathrm{P} 1=68,596 ; \mathrm{P} 2=75,160 \mathrm{mg}$ $\mathrm{kg}^{-1}$; values for Bo horizon), while in the lower third there was a drastic reduction ( $\mathrm{P} 3=53,297 \mathrm{mg} \mathrm{kg}^{-1}$; Bo horizon). During fieldwork, it was observed that the hues were redder in P1 and P2 and yellower in P3. In the lower third of the landscape, where more water tends to accumulate, in addition to the lower Fe content, the formation of goethite over hematite is favored, making this soil yellower than the others (Figure 3a). Table 3 shows more available $\mathrm{Fe}$ content in the Bo horizon of $\mathrm{P} 3$, which is possibly due to a greater moisture degree, favoring some seasonal reduction of $\mathrm{Fe}$ (III) and consequent increase of $\mathrm{Fe}(\mathrm{II})$ compounds (Resende et al., 2021; Kämpf; Curi, 2012; Schwertmann; Taylor, 1989). There is no certainty as to why the drainage regime is different in $\mathrm{P} 3$, but all mentioned evidences showed that it is distinct from $\mathrm{P} 1$ and $\mathrm{P} 2$. The main hypotheses for this phenomenon are the proximity to the parent material (and thus the water table), and the retention of water due to the higher SOM content.
Values of silica/alumina ratio for Bo horizons were 0.83 in $\mathrm{P} 1,0.81$ in $\mathrm{P} 2$, and 1.22 in $\mathrm{P} 3$ (Table 4). The other indexes show a similar behavior, indicating higher weathering degree in the Bo horizon (except for P3), which was completely unexpected. This trend can be observed in all three studied soil profiles (Table 4) and indicates a pre-weathering of these soils, facilitated by the mafic lamellae of the gneiss (Mancini et al., 2021), probably in a flatter paleorelief, in accordance with the geomorphology (section 3.4).

According to the weathering degree indexes (Equations 1, 2 and 3), in P3 the weathering is less intense than in $\mathrm{P} 1$ and $\mathrm{P} 2$, corroborating the aforementioned discussions. Overall, the studied profiles tend to be less weathered down the slope. The decreasing weathering degree order was: P1 $\geq$ P2 $>$ P3 (Table 4). Additionally, $\mathrm{P} 1$ and $\mathrm{P} 2$ show increasing weathering degree from $\mathrm{A}$ to $\mathrm{Bo}$, whilst in $\mathrm{P} 3$ the $\mathrm{AB}$ horizon is more weathered than Bo. This trend is likely an indication that soils are getting closer to the parent material and/or are less weathered 
due to poorer drainage compared to $\mathrm{P} 1$ and $\mathrm{P} 2$. This trend agrees with previously mentioned observations. For instance, soils gradually become yellower down the slope, indicating poorer drainage, which favors the formation of goethite (yellow) over hematite (red) (Table 2); and SOM increases down the slope, evidence of a decrease in drainage efficiency (Table 3).

Table 4: Weathering degree indexes for the studied Oxisol profiles, situated in Muzambinho municipality, Minas Gerais state, Brazil.

\begin{tabular}{ccccc}
\hline Soil & Horizon & $\mathrm{Di}^{1}$ & $\mathrm{Ri}^{2}$ & $\mathrm{Zi}^{3}$ \\
\hline \multirow{3}{*}{ P1 } & $\mathrm{A}$ & 0.67 & 1.05 & 0.71 \\
& $\mathrm{AB}$ & 0.69 & 1.13 & 0.73 \\
& $\mathrm{Bo}$ & 0.48 & 0.83 & 0.51 \\
\hline \multirow{3}{*}{ P2 } & $\mathrm{A}$ & 0.70 & 1.12 & 0.73 \\
& $\mathrm{AB}$ & 0.57 & 0.95 & 0.61 \\
& $\mathrm{Bo}$ & 0.51 & 0.81 & 0.53 \\
\hline \multirow{3}{*}{ P3 } & $\mathrm{A}$ & 0.87 & 1.29 & 0.91 \\
& $\mathrm{AB}$ & 0.78 & 1.15 & 0.82 \\
& $\mathrm{Bo}$ & 0.83 & 1.22 & 0.87 \\
\hline
\end{tabular}

${ }^{1} \mathrm{Di}=\frac{\mathrm{SiO}_{2}}{\left(\mathrm{Al}_{2} \mathrm{O}_{3}+\mathrm{Fe}_{2} \mathrm{O}_{3}+\mathrm{TiO}_{2}\right)}$ (Singh; Parkash; Singhvi, 1998);

$2 \mathrm{Ri}=\frac{\mathrm{SiO}_{2}}{\mathrm{Al}_{2} \mathrm{O}_{3}}$ (Ruxton, 1968);

${ }^{3} \mathrm{Zi}=\frac{\mathrm{SiO}_{2}}{\left(\mathrm{Al}_{2} \mathrm{O}_{3}+\mathrm{Fe}_{2} \mathrm{O}_{3}\right)}$ (Zhang, Hartemink, 2019).

The Al behavior was different in each soil profile (Figure 3a). Aluminum has high concentration in old soils as a residual element, mainly associated with gibbsite and kaolinite in the clay fraction, and in micas, mainly muscovite, in the sand fraction (Brinatti et al., 2010). The $\mathrm{Al}$ random distribution in these soils, assessed by $\mathrm{pXRF}$, is probably related to the alternating felsic and mafic laminae of the gneiss, as observed by Mancini et al. (2021) in this region.

In Figure 3b, we can see that Ti contents have a maximum value of $12,000 \mathrm{mg} \mathrm{kg}^{-1}$. Titanium is a less mobile element in soils, being frequently used as a fingerprint of soil parent material (Mancini et al., 2021), and these Oxisols derived from gneiss have lower contents compared to other Oxisols derived from mafic rocks (Ker; Novais, 2011). The Ti oxide minerals frequently found in soils, such as ilmenite $\left(\mathrm{FeTiO}_{3}\right)$ and anatase $\left(\mathrm{TiO}_{2}\right)$, are originated from the weathering of silicates like biotite, hornblende, and augite; Ti can also be found as isomorphous substituent of $\mathrm{Fe}$ and $\mathrm{Al}$ in the crystalline structure of oxide minerals (Andrade et al., 2009; Araujo et al., 2014).

Mn (Figure 3c) showed little variation across the soil profiles. It was observed a little enrichment with depth in $\mathrm{P} 1$ and $\mathrm{P} 2$ compared with the Mn superficial quantity: A horizon $\left(\mathrm{P} 1=202 ; \mathrm{P} 2=212 \mathrm{mg} \mathrm{kg}^{-1}\right)$ and $\mathrm{Bo}(\mathrm{P} 1=254$; $\left.\mathrm{P} 2=237 \mathrm{mg} \mathrm{kg}^{-1}\right)$. This element has a large abundance in the terrestrial crust; there is a great diversity of Mn-bearing minerals in soils and parent materials, such as plagioclases, olivines, pyroxenes, amphiboles and biotites (Andrade et al., 2009). Mn differences between profiles observed herein (Figure 3c) can be explained by the accessory minerals in parent material composition.

\section{Correlations between texture, fertility attributes and $\mathrm{pXRF}$ data}

The correlation between total $\mathrm{Fe}$ and Ti contents (pXRF) with the sand fraction content was high and negative ( -0.92 and -0.87 , respectively), probably due to the fact the dominant minerals in this soil fraction of Oxisols are quartz and muscovite (Figure 4a), which do not contain such elements in their crystalline structure. Conversely, clay ( 0.53 and 0.48$)$ and silt ( 0.52 and 0.54 , respectively) fractions had a positive correlation with these elements contents, due to the presence of hematite $\left(\mathrm{Fe}_{2} \mathrm{O}_{3}\right)$, maghemite $\left(\mathrm{Fe}_{2} \mathrm{O}_{3}\right)$, goethite $(\mathrm{FeOOH})$, ilmenite $\left(\mathrm{FeTiO}_{3}\right)$, rutile $\left(\mathrm{TiO}_{2}\right)$ and anatase $\left(\mathrm{TiO}_{2}\right)$ in these soil fractions of Oxisols. Iron is usually strongly correlated to soil texture (Figure 4a), mainly to the clay fraction, which was also observed by O'Rourke et al. (2016).

A strong and positive correlation $(0.98 ; \mathrm{p}<0.05)$ between Fe and Ti total contents was observed, which is explained by their similar behavior, residually accumulating in Oxisol profiles (Figure 4a). For Al, Mn and $\mathrm{Si}$ contents, weak correlations were found to any textural fraction, probably because they occur in minerals of multiple particle size fractions. For instance, Al may be present in the muscovite crystalline structure in the sand (more common) and silt (less common) fractions, as well as in kaolinite, gibbsite and Fe oxide minerals in the silt and clay fractions of Oxisols. Mn may be an isomorphous substituent of $\mathrm{Fe}$ in the oxide minerals in the latter soil fractions of Oxisols. Muscovite, kaolinite and quartz also present $\mathrm{Si}$ in their composition, and as these minerals can occur in different particle size fractions of Oxisols (Kämpf; Marques; Curi, 2012), strong and positive correlations between this element and the particle size fractions of these soils do not happen. 


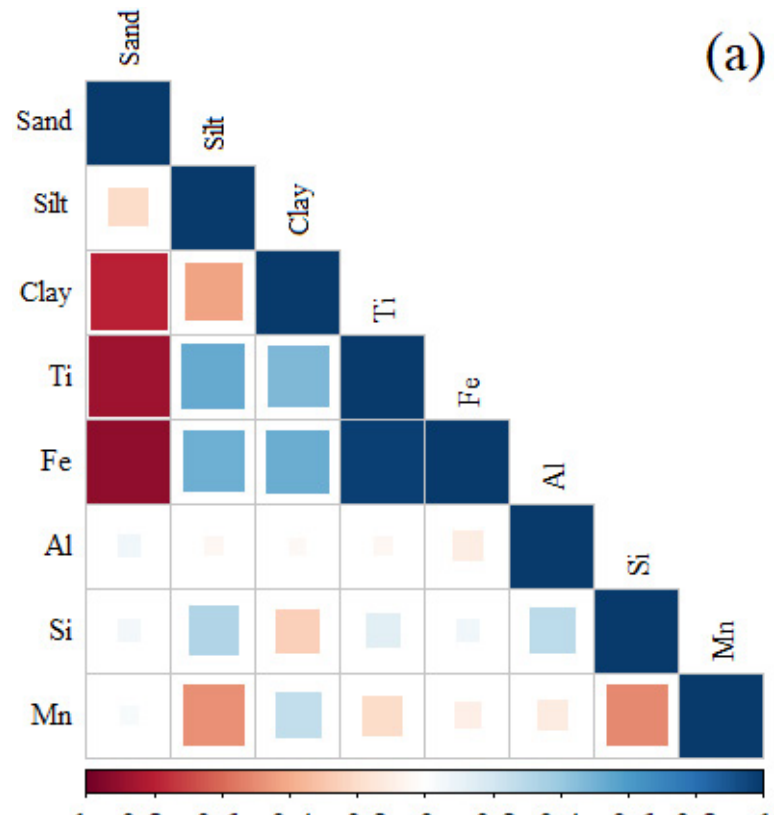

$\begin{array}{lllllllllll}-1 & -0.8 & -0.6 & -0.4 & -0.2 & 0 & 0.2 & 0.4 & 0.6 & 0.8 & 1\end{array}$

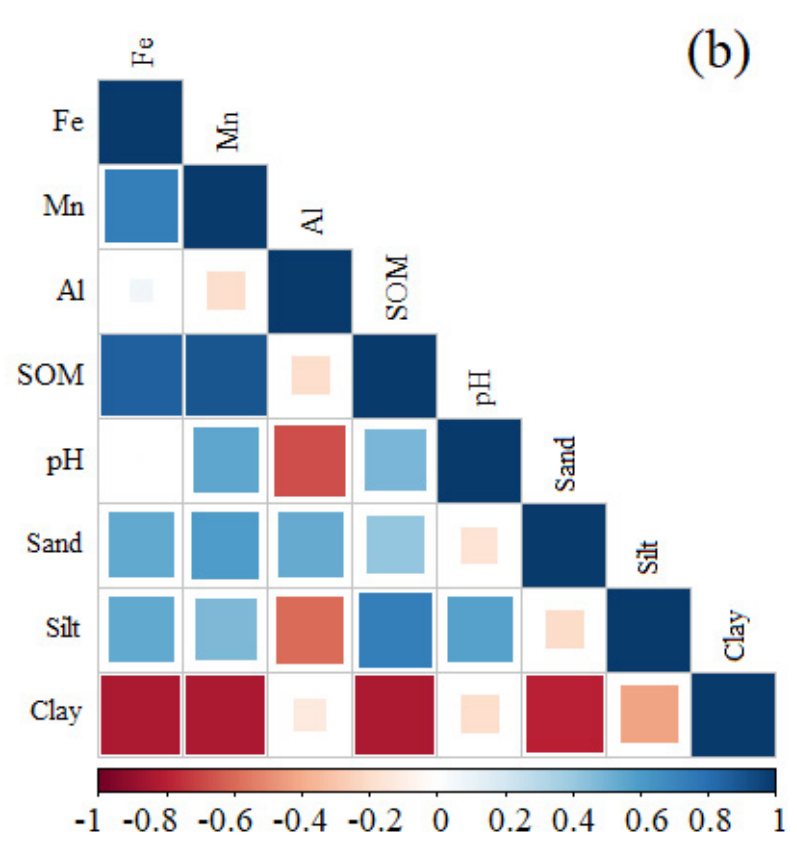

Figure 4: Correlations between soil texture and pXRF data (a) and between soil texture and fertility analyses (b). Data from composite samples of horizons of the Oxisol profiles located at the IFSULDEMINAS, Muzambinho municipality, Minas Gerais state, southeastern Brazil.

Available contents of Fe and Mn had a strong correlation with the SOM (Figure $4 \mathrm{~b}: 0.86$ and 0.90 , respectively; $\mathrm{p}<0.05$ ), which can be explained by their adsorption onto SOM, due to their opposite superficial electrical charges (Franks et al., 2021; Lana et al., 2014). The available contents of $\mathrm{Fe}$ and $\mathrm{Mn}$ were negatively correlated to the clay fraction $(-0.83$ and $-0.84 ; \mathrm{p}<0.05$ respectively), probably because of the low-activity clays in these soils. The relationships between available $\mathrm{Fe}$ and $\mathrm{Mn}$ contents were strong and positive $(0.73 ; \mathrm{p}<0.05)$ because of their similar behavior in Oxisols.

The relations found in Figure $4 \mathrm{~b}$ between texture and SOM for Oxisols differed from Zinn, Lal and Resck (2005). The mentioned authors detected no significant correlations between clay contents and SOC in soils of the Brazilian Cerrado; yet, here, the clay content had a high negative $(-0.83 ; \mathrm{p}<0.05)$ correlation with SOM. This could be related to the different biomes where these Oxisols are situated: soils studied herein belong to the Atlantic Forest biome, which has several different attributes compared to the Cerrado biome (Curi et al., 2017).

The exchangeable $\mathrm{Al}^{3+}$ content had a negative correlation $(-0.67 ; \mathrm{p}<0.05)$ with soil $\mathrm{pH}$ because of the dominance of hydroxide forms of $\mathrm{Al}$ as the $\mathrm{pH}$ increases, favored by liming application in the superficial horizons of soils in this area (Lopes; Guilherme, 2016).

\section{Geomorphology and pedogenesis}

Oxisols are usually associated with stable, flat surfaces, and with hot, humid climate. At the beginning of their formation, when the fresh rock was starting to weather, there should have been no structure developed enough to stop particles from being transported in case the rock was situated in a steep slope. Hence, for the rock to be weathered under hot and humid climate without having its particles eroded away and deposited elsewhere (pedogenesis < erosion), the soils studied here must have formed and deepened for a long period under smooth surfaces (pedogenesis $>$ erosion).

The studied soils, however, are nowadays situated in a very steep slope (Figure 1). Their paradoxical depth and landscape position indicate two aspects: i) they were certainly formed under past landforms; and ii) a lot of weathering and formation happened before these landforms changed significantly. These soils likely developed in a preceding flat surface during intense periods of weathering-leaching. Today, they are progressively exposed as present-day landforms are carved and become steeper (Bigarella, Mousinho, 
Silva, 2016; Resende et al., 2014). This interpretation is supported by the fact that since a long time ago the Brazilian territory has been submitted to very intense water erosion, and as a consequence some strata from the geologic column, common in another parts of world, are absent in Brazil (Resende et al., 2019).

It is true that soils from temperate regions commonly begin their pedogenetic processes as glaciers recede and form new erosional surfaces (Sanborn, 2016; Tsai et al., 2016) - that is, soils are more closely related to erosion surfaces and their ages. However, soils from the studied area and similar tropical regions in southeastern Brazil have developed continuously since ancient times and are now becoming shallower in some cases, as landforms are carved by recent drainage systems. Many soil classes are thus less related to their respective erosional surfaces, since they were formed previously and are now being dissected.

An important evidence to consolidate this idea is the coinciding altitude of hilltops throughout the region (King, 1956; Resende et al., 2019) (Figure 5). Although altitude differences between regions may exist due to subsidence and other geological processes, many hilltops across large areas have barely the same altitude. This is a clear indication that in the past this region had large portions of flatter relief. The strongly undulated relief observed now indicates an erosion resumption, caused by the lowering of the base level during a somewhat drier climate (Resende et al., 2021). The old, weathered and flat landforms were hence dissected and resulted in a rugged landscape with absence of rock outcrops and many deep, nutrient-poor soils, even in steep slopes.
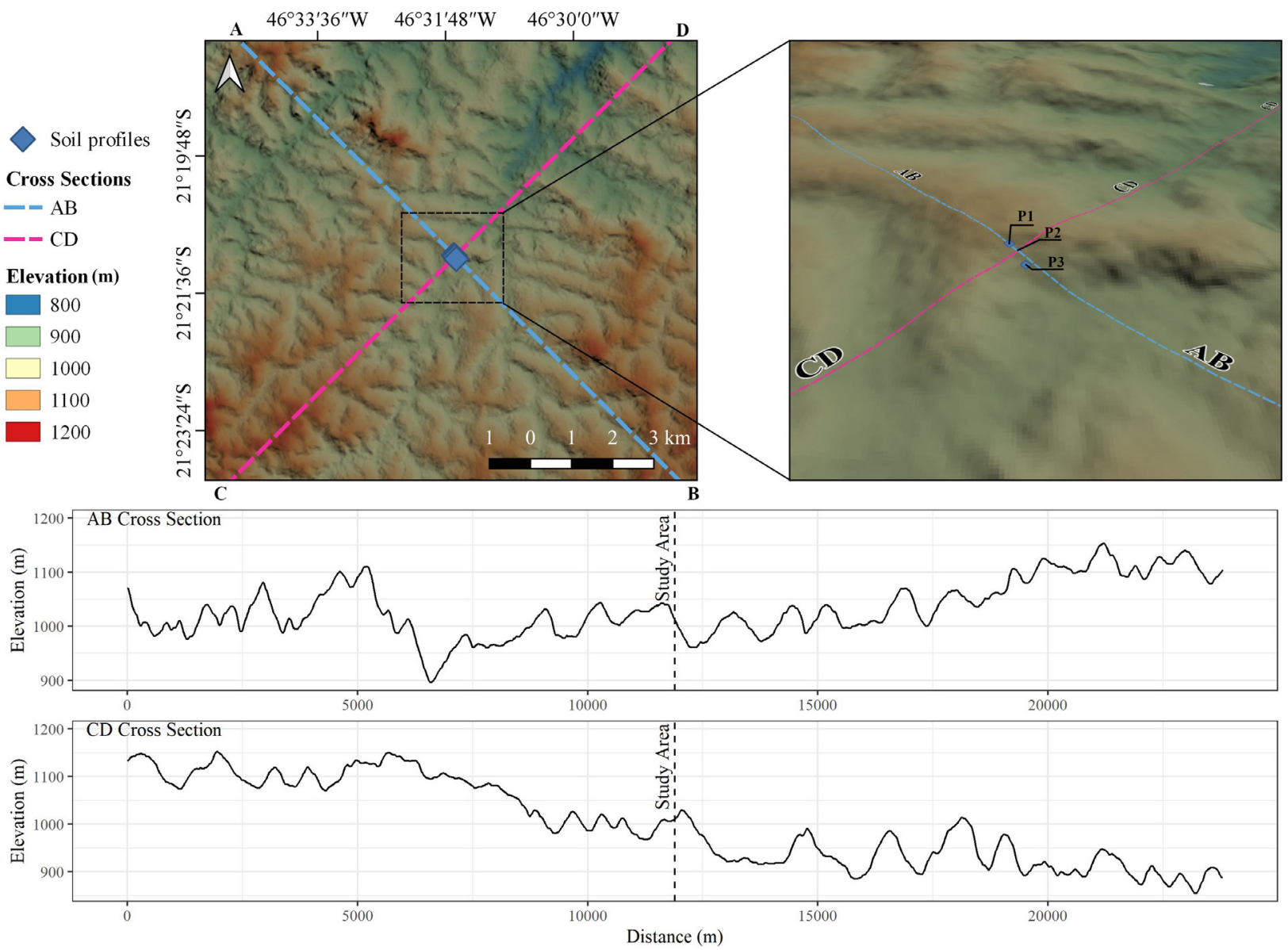

Figure 5: Two cross sections showing the concordance of hilltop altitudes around the study area in the Muzambinho municipality, Minas Gerais state, Brazil. Distance is measured from the points A and C to points $B$ and D. The points were chosen arbitrarily. Dashed lines show the location of the study area within the cross sections. P1: Profile 1; P2: Profile 2; P3: Profile 3. 


\section{CONCLUSIONS}

Soils were successfully characterized quickly and at low cost with the aid of pXRF. Chemical analysis highlighted traits of the parent material (e.g., Al and $\mathrm{Fe}$ contents) and showed that all three studied soils are dystrophic. This is evidence of a deep, nutrient-poor regolith even in lower positions of the hill. The soil weathering indexes calculated from $\mathrm{pXRF}$ data showed the advanced stage of aging of these soils even in strongly undulated relief. Weathering degree was higher in Bo horizon than in superficial horizons indicating preweathering of these soils. The weathering degree tended to decrease down the slope. The decreasing weathering degree order for the studied soils was: P1 $\geq$ P2 $>$ P3. The great depth of these soils even in the steepest parts of the slope are evidence that pedogenesis happened mainly prior to current landforms. The idea of a flat paleorelief is supported by the absence of rock outcrops and the concordance of altitude of the surrounding summits, and helps to explain the abnormal soil-landscape relationships observed today in this physiographic region. After their formation, the resumption of erosional processes dissected the landscape, exposing deeper parts of these ancient soils, but not yet reaching the parent rock (gneiss).

\section{AUTHOR CONTRIBUTION}

Conceptual idea: Bócoli, F.A.; Santos, W.J.R.; Silva, S.H.G.; Curi, N.; Methodology design: Bócoli, F.A.; Santos, W.J.R.; Data collection: Bócoli, F.A.; Santos, W.J.R.; Data analysis and interpretation: Bócoli, F.A.; Silva, S.H.G.; Teixeira, A.F.S.; Mancini, M.; Curi, N.; and Writing and editing: Bócoli, F.A.; Teixeira, A.F.S.; Mancini, M.; Curi, N.

\section{ACKNOWLEDGMENTS}

The authors would like to thank the Programa Institucional de Bolsa de Iniciação Científica (PIBIC) of the Instituto Federal de Educação Ciência e Tecnologia do Sul de Minas Gerais, Campus Muzambinho, and the institution facilities and equipments availability to this study realization. Also, we acknowledge CNPq, CAPES and FAPEMIG for financial research support.

\section{REFERENCES}

ALVARES, C. A. et al. Koppen's climate classification map for Brazil. Meteorologische Zeitschrift, 22(6):711-728, 2013.

ANDRADE, J. C. et al. Química e mineralogia do solo: Parte 1 Conceitos básicos. Viçosa- MG: SBCS, 2009. 695p.
APARECIDO, L. E. D. O. et al. Análise climática para a Região de Muzambinho - MG. In: IX WORKSHOP DE PÓSGRADUAÇÃO E PESQUISA DO CENTRO PAULA SOUZA. Estratégias Globais e Sistemas Produtivos Brasileiros. 2014. Available in: <http://www.pos.cps.sp.gov.br/files/artigo/ file/448/988359afb8f7f48f991981ae72f35943.pdf>. Access in: October, 18, 2021.

ARAUJO, M. A. et al. Paragênese mineral de solos desenvolvidos de diferentes litologias na região sul de Minas Gerais. Revista Brasileira de Ciência do Solo, 38(1):11-25, 2014.

BATISTA, R. M.; SANTOS, W. J. R. Mapeamento semi-detalhado de solos do IFSULDEMINAS - Campus Muzambinho por meio de técnicas de mapeamento digital de solos. Available in: <https://jornada.ifsuldeminas.edu.br/index. php/jcmch4/jcmch4/paper/viewFile/3249/2396>. Access in: October, 18, 2021.

BERGER, K. C.; TRUOG, E. Boron determination in soils and plants. Industrial \& Engineering Chemistry Analytical Edition, 11(10):540-545, 1939.

BIGARELLA, J. J.; MOUSINHO, M. R. da.; SILVA, J. X. Pediplanos, pedimentos e seus depósitos correlativos no Brasil. Espaço Aberto, 6(2):165-196, 2016.

BRINATTI, A. M. et al. Mineralogical characterization of a highlyweathered soil by the Rietveld Method. Scientia Agricola, 67(4):454-464, 2010.

CAMPOS, M. C. C. et al. Topossequência de solos na transição campos naturais-floresta na região de Humaitá, Amazonas. Acta Amazonica, 42(3):387-398, 2012.

CANELLAS, L. P. et al. Frações da matéria orgânica em seis solos de uma toposseqüência no Estado do Rio de Janeiro. Pesquisa Agropecuária Brasileira, 35(1):133-143, 2000.

CHAKRABORTY, S. et al. Use of portable X-ray fluorescence spectrometry for classifying soils from different land use land cover systems in India. Geoderma, 338:5-13, 2019.

CURI, N. et al. Mapeamento de solos e magnetismo no campus. Lavras: Editora UFLA, 2017. 148p.

CURI, N.; FRANZMEIER, D. P. Toposequence of oxisols from the Central Plateau of Brazil. Soil Science Society of America Journal, 48(2):341-346, 1984.

DONAGEMA, G. K. et al. Manual de métodos de análise de solo. $2^{a}$ ed. Rio de Janeiro: Embrapa Solos, 2011. 230p.

FAGERIA, N. K. Role of soil organic matter in maintaining sustainability of cropping systems. Communications in Soil Science and Plant Analysis, 43(16):2063-2113, 2012. 
FOOD AND AGRICULTURE ORGANIZATION - FAO. World reference base for soil resources/ International soil classification system for naming soils and creating legends for soil maps. Rome: Food and Agriculture Organization of the United Nations, 2014. 191p.

FRANKS, M. et al. Role of Fe- and Mn-(oxy)hydroxides on carbon and nutrient dynamics in agricultural soils: A chemical sequential extraction approach. Chemical Geology, 561:120035, 2021.

GEE, G. W.; BAUDER, J. W. Particle-size analysis. In: KLUTE, A. (Ed.). Methods of soil analysis. Madison: American Society of Agronomy, p. 38-412, 1986.

GOZUKARA, G.; ZHANG, Y.; HARTEMINK, A. E. Using vis-NIR and pXRF data to distinguish soil parent materials - An example using 136 pedons from Wisconsin, USA. Geoderma, 396:115091, 2021.

HORTA, A. et al. Integrating portable X-ray fluorescence (pXRF) measurement uncertainty for accurate soil contamination mapping. Geoderma, 382:114712, 2021.

IBÁÑEZ-ASENSIO, S. et al. Statistical relationships between soil colour and soil attributes in semiarid areas. Biosystems Engineering, 116(2):120-129, 2013.

INDA JUNIOR, A. V. et al. Fundamentos de química do solo. 6. ed. Porto Alegre: Biblioteca Setorial da Faculdade de Agronomia da UFRGS, 2017. 266p.

JENNY, $\mathrm{H}$. Factors of soil formation: A system of quantitative pedology. New York: McGraw-Hill Book Co., Inc., 1941. 281 p.

KÄMPF, N.; CURI, N. Formação e evolução do solo (Pedogênese). In: KER, J. C. et al. (Eds.). Pedologia Fundamentos. 1. ed. Viçosa, MG: SBCS, p. 207-302, 2012.

KÄMPF, N.; CURI, N. Argilominerais em solos brasileiros. In: CURI, N. et al. (Eds.). Tópicos em ciência do solo, vol. 3. Viçosa, MG: SBCS, p. 1-54, 2003.

KÄMPF, N.; MARQUES, J. J.; CURI, N. Mineralogia de Solos Brasileiros. In: KER, J. C. et al. (Eds.). Pedologia Fundamentos. 1. ed. Viçosa, MG: SBCS, p. 81-146, 2012.

KÄMPF, N.; CURI, N.; MARQUES, J. J. Intemperismo e ocorrência de minerais no ambiente do solo. In: MELO, V. F.; ALLEONI, L. R. F. (Eds.). Química e mineralogia do solo - Parte I: Conceitos básicos. Viçosa, MG: SBCS, p. 333-380, 2009.

KEBONYE, N.M. et al. Comparison of multivariate methods for arsenic estimation and mapping in floodplain soil via portable X-ray fluorescence spectroscopy. Geoderma, 384:114792, 2021.
KER, J. C. Latosols do Brasil: uma revisão. Geonomos, 5(1):1740, 1998.

KER, J. C. et al. Pedologia: Fundamentos. Viçosa: Sociedade Brasileira de Ciência do Solo, 2012. 343p.

KER, J. C.; NOVAIS, R. F. de. Fundamentos para desenvolvimento da pedologia e da fertilidade do solo. 2011. Available in: <http://jararaca.ufsm.br/websites/classolos/download/ TextosSol/Texto03.pdf>. Accessed in: October, 18, 2021.

KING, L. C. A geomorfologia do Brasil oriental. Revista Brasileira de Geografia, 18(2):147-265, 1956.

LANA, R. M. Q. et al. Ferro e manganês no perfil do solo em Saccharum officinalis fertilizada com resíduos orgânicos. Bioscience Journal, 30:131-140, 2014.

LEPSCH, I. F. Formação e Conservação dos Solos. 2. ed. São Paulo: Oficina de Textos, 2010. 216p.

LIMA, T. M. de. et al. Elemental analysis of Cerrado agricultural soils via portable X-ray fluorescence spectrometry: Inferences for soil fertility assessment. Geoderma, 353:264-272, 2019.

LOPES, A. S.; GUILHERME, L. R. G. A career perspective on soil management in the Cerrado region of Brazil. In: SPARKS, D. L. (Ed.). Advances in Agronomy. Academic Press, v. 137, p.1-72, 2016.

MANCINI, M. et al. Formation and variation of a $4.5 \mathrm{~m}$ deep oxisol in southeastern Brazil. Catena, 216:105492, 2021.

MANCINI, M. et al. Parent material distribution mapping from tropical soils data via machine learning and portable X-ray fluorescence (pXRF) spectrometry in Brazil. Geoderma, 354:113885, 2019.

MCLEAN, E. O. et al. Aluminum in soils: I. Extraction methods and magnitudes in clays and ohio soils1. Soil Science Society of America Journal, 22(5):382-387, 1958.

MEHLICH, A. Determination of $\mathrm{P}, \mathrm{Ca}, \mathrm{Mg}, \mathrm{K}, \mathrm{Na}$ and $\mathrm{NH}_{4}$. Raleigh: North Carolina Soil Testing Division, 1953. 16p.

MONIZ, A. C.; BUOL, S. W. Formation of an oxisol-ultisol transition in Săo Paulo, Brazil. Soil Science Society of America Journal, 46(6):1228-1232, 1982.

O'ROURKE, S. M. et al. An assessment of model averaging to improve predictive power of portable vis-NIR and XRF for the determination of agronomic soil properties. Geoderma, 279:31-44, 2016.

PELEGRINO, M. H. P. et al. Prediction of soil nutrient content via pXRF spectrometry and its spatial variation in a highly variable tropical area. Precision Agriculture, 1-17, 2021. 
R CORE TEAM. R: A language and environment for statistical computing. R Foundation for Statistical Computing, Vienna, Austria, 2021. Version 4.1.1. Available in: <https://www.rproject.org/>. Access in: October, 18, 2021.

RESENDE, M. et al. Mineralogia de solos Brasileiros: Interpretação e aplicações. 2. ed. Lavras - MG: Editora UFLA, 2011. 201p.

RESENDE, M. et al. Pedologia: Base para distinção de ambientes. 6. ed. Lavras: Editora UFLA, 2014. 378p.

RESENDE, M. et al. Da rocha ao solo: Enfoque ambiental. 1. ed. Lavras - MG: Editora UFLA, 2019. 513p.

RESENDE, M. et al. Pedologia, fertilidade, água e planta: Interrelações e aplicações. 2. ed. Lavras - MG: Editora UFLA, 2021. 263p.

RUXTON, B. P. Measures of the degree of cliemical weathering of rocks. Journal of Geology, 76(5):518-527, 1968.

SANBORN, P. The imprint of time on canadian soil landscapes. Quaternary International, 418:165-179, 2016.

SANTOS, H. G. dos. et al. Sistema brasileiro de classificação de solos. $5^{\text {a }}$ ed. Brasília: Embrapa, 2018. 589p.

SANTOS, R. D. dos. et al. Manual de descrição e coleta de solo no campo. 6. ed. Viçosa: Sociedade Brasileira de Ciência do Solo, 2015. 102p.

SCHWERTMANN, U.; TAYLOR, R. M. Iron oxides. In: DIXON, J. B.; WEED, S. B. (Eds.). Minerals in soil environments. 2nd. ed. Madison: Soil Science Society of America, p. 379-438, 1989.

SHOEMAKER, H. E.; MCLEAN, E. O.; PRATT, P. F. Buffer methods for determining lime requirement of soils with appreciable amounts of extractable aluminum. Soil Science Society of America Journal, 25(4):274, 1961.

SILVA, S. et al. Proximal sensing and digital terrain models applied to digital soil mapping and modeling of Brazilian Latosols (Oxisols). Remote Sensing, 8:614-635, 2016.

SILVA, S. H. G. et al. Soil weathering analysis using a portable $X$-ray fluorescence (PXRF) spectrometer in an Inceptisol from the Brazilian Cerrado. Applied Clay Science, 162:27-37, 2018.

SILVA, S. H. G. et al. Modeling and prediction of sulfuric acid digestion analyses data from PXRF spectrometry in tropical soils. Scientia Agricola, 77(4):e20180132, 2020.

SILVA, S. H. G. et al. pXRF in tropical soils: Methodology, applications, achievements and challenges. In: SPARKS, D. L. (Ed.). Advances in Agronomy. Academic Press, p. 1-62, 2021.
SINGH, L. P.; PARKASH, B.; SINGHVI, A. K. Evolution of the lower gangetic plain landforms and soils in West Bengal, India. Catena, 33(2):75-104, 1998.

SOIL SURVEY STAFF. Keys to soil taxonomy. 12. ed. United States Department of Agriculture Natural Resources Conservation Service, 2014. v. 12. 410p.

STOCKMANN, U. et al. Utilizing portable X-ray fluorescence spectrometry for in-field investigation of pedogenesis. Catena, 139:220-231, 2016.

SUN, F. et al. Enhanced soil profile visualization using portable X-ray fluorescence (PXRF) spectrometry. Geoderma, 358:113997, 2020.

SWANHART, S. et al. Soil salinity measurement via portable $x$-ray fluorescence spectrometry. Soil Science, 179(9):417-423, 2014.

TEIXEIRA A. F. S. dos. et al. Soil physicochemical properties and terrain information predict soil enzymes activity in phytophysiognomies of the Quadrilátero Ferrífero region in Brazil. Catena, 199:105083, 2021.

TSAI, H. et al. Soilscape of west-central Taiwan: Its pedogenesis and geomorphic implications. Geomorphology, 255:81-94, 2016.

WALKLEY, A.; BLACK, I. A. An examination of the Degtjareff method for determining soil organic matter and a proposed modification of the chromic acid titration method. Soil Science, 37(1):29-38, 1934.

WEI, T.; SIMKO, V. R package 'corrplot': Visualization of a correlation matrix. 2021. Version 0.90. Available in: <https:// cran.r-project.org/web/packages/corrplot/index.html>. Access in: October, 18, 2021.

WEINDORF, D. C.; BAKR, N.; ZHU, Y. Advances in Portable X-ray Fluorescence (PXRF) for Environmental, Pedological, and Agronomic Applications. In: SPARKS, D. L. (Ed.). Advances in Agronomy. Academic Press, p. 1-45, 2014.

WEINDORF, D. C.; CHAKRABORTY, S. Portable X-ray fluorescence spectrometry analysis of soils. In: HIRMAS, D. (Ed.). Methods of soil analysis. Madison: Soil Science Society America, p. 1-8, 2016.

ZHANG, Y.; HARTEMINK, A. E. Digital mapping of a soil profile. European Journal of Soil Science, 70(1):27-41, 2019.

ZHU, Y.; WEINDORF, D.C.; ZHANG, W. Characterizing soils using a portable X-ray fluorescence spectrometer: 1. Soil texture. Geoderma, 167-168:167-177, 2011.

ZINN, Y. L.; LAL, R.; RESCK, D. V. S. Texture and organic carbon relations described by a profile pedotransfer function for Brazilian Cerrado soils. Geoderma, 127(1-2):168-173, 2005. 